\title{
Aymara Language
}

National Cancer Institute

\section{Source}

National Cancer Institute. Aymara Language. NCI Thesaurus. Code C153846.

An Aymaran language spoken by the Aymara people of the Andes and by some

communities in northern Chile. 